\title{
The EPICA deep ice cores: first results and perspectives
}

\author{
Bernhard STAUFFER, ${ }^{1}$ Jacqueline FLÜCKIGER, ${ }^{1}$ Eric WOLFF, ${ }^{2}$ Piers BARNES ${ }^{2 *}$ \\ ${ }^{1}$ Physics Institute, University of Bern, Sidlerstrasse 5, CH-3012 Bern, Switzerland \\ E-mail: bernard.stauffer@bluewin.ch \\ ${ }^{2}$ British Antarctic Survey, Natural Environment Research Council, Madingley Road, Cambridge CB3 OET, UK
}

\begin{abstract}
Two deep ice cores are being drilled in Antarctica in the frame of the European Project for Ice Coring in Antarctica (EPICA). The Dome C ice core will provide more information about mechanisms of global climatic changes over several climatic cycles. The DML core, drilled at Kohnen station, will provide a detailed record over the last climatic cycle, which can be compared with Greenland records. The drilling at Dome $C$ reached $3200 \mathrm{~m}$ depth during field season 2002/03, and the age of the ice at the bottom of the hole could be 900000 years according to preliminary estimates. The depth at Kohnen station is $1564.6 \mathrm{~m}$ at present, corresponding to an age of about 55000 years. Analyses along the top parts of both ice cores have provided interesting first results. A few selected results from these parts, mostly published already, are summarized. Only a few measurements are available from the deeper parts of both cores. Dielectric profiling and electrical conductivity measurements, performed in the field, provide continuous and high-resolution records concerning the acidity and the salt concentration of the ice. Continuous flow analyses and Fast lon Chromatography also provide highresolution records of several chemical compounds. These records give some clues as to the age scale of the EPICA Dome C ice core, but they also leave us with many open questions.
\end{abstract}

\section{INTRODUCTION}

The main objective of the European Project for Ice Coring in Antarctica (EPICA) is to investigate further climatic variations in the Southern Hemisphere and especially their mechanisms in the past. The time-scales range from centuries to several hundred thousand years. It soon became obvious that at least two ice cores from different locations would be needed to reach the envisaged goals. Therefore, it was decided to perform two core drillings: one in the area of Wilkes Land adjacent to the Pacific Ocean, the other in Dronning Maud Land (DML), adjacent to the South Atlantic Ocean. The first should allow extension of the ice-core record back to at least five climatic cycles; the second should provide a good time resolution for the last climatic cycle and allow, due to its proximity to the Atlantic Ocean, a detailed comparison with the Greenland records. The drilling of two deep ice cores in locations diametrically apart on the Antarctic ice sheet has been facilitated by the fact that European nations can offer existing logistic infrastructures in both areas.

For the first core drilling, a site in the area of Dome $\mathrm{C}$ was envisaged. Based on a site survey using radar echo sounding and surface topography determinations (Tabacco and others, 1998), a site with a flat bedrock at $75^{\circ} 06^{\prime} 02^{\prime \prime} \mathrm{S}, 123^{\circ} 20^{\prime} 52^{\prime \prime} \mathrm{E}$ was selected. The location, Concordia Station, is close to the topographic summit: the elevation is $3233 \mathrm{~m}$ a.s.l., the mean annual temperature $-54.5^{\circ} \mathrm{C}$ and the mean annual accumulation rate about $25.0 \mathrm{~kg} \mathrm{~m}^{-2}$. During field season 1996/97 a camp was constructed and was prepared for deep core drilling by installing a casing to $120 \mathrm{~m}$ depth. Core drilling reached $364 \mathrm{~m}$ depth during the following field season, and $781.6 \mathrm{~m}$ in December 1998, but at this depth the drill got stuck and could not be recovered. Drilling had to restart from the surface in December 2000. A depth of $1458.2 \mathrm{~m}$

*Present address: CSIRO Industrial Physics, P.O. Box 218, Lindfield, Sydney, New South Wales 2070, Australia. was reached during field season 2000/01, and a depth of $2871 \mathrm{~m}$ in February 2002. Drilling became difficult due to the increasing temperature at this depth which causes a remarkable change in the mechanical properties of the ice and, more importantly, in the ice cuttings produced during drilling. Therefore, it was no surprise that drilling progress during field season 2002/03 was relatively modest, and bedrock, expected at about $3300 \mathrm{~m}$, could not be reached. The present depth is $3200.01 \mathrm{~m}$, and a further $100 \mathrm{~m}$ of very difficult core drilling is needed to reach bedrock.

Core processing and first analyses had already been performed at Dome C. Ice cores were inspected, registered and sectioned for various types of analyses, which will be conducted back in European laboratories. Dielectric profiling (DEP; Moore, 1993) was performed on the entire core, and electrical conductivity measurements (ECM) on a freshly cut surface of the core. From the core a prismatic 'sub-core' with a cross-section of $34 \times 34 \mathrm{~mm}^{2}$ is cut and melted continuously. The construction of the melt head allows the separation of water from the central part of the sub-core from that of the outer part. The uncontaminated water from the central part is used for continuous flow analyses (CFA) to determine the concentrations of $\mathrm{Ca}^{2+}$, $\mathrm{Na}^{+}, \mathrm{NH}_{4}{ }^{+}, \mathrm{NO}_{3}{ }^{-}, \mathrm{H}_{2} \mathrm{O}_{2}, \mathrm{HCHO}$ and dust, as well as electrical conductivity of meltwater (Röthlisberger and others, 2000), and Fast Ion Chromatography (FIC), to determine the concentrations of $\mathrm{SO}_{4}{ }^{2-}, \mathrm{NO}_{3}{ }^{-}$and $\mathrm{Cl}^{-}$ (Udisti and others, 2000). The remaining part is collected in Coulter Accuvette sample containers for additional chemical analyses by ion chromatography in different laboratories in Europe. A small cross-section of the core is also used to make investigations of the physical properties in the field.

In DML, which does not have a major dome structure, a more elaborate survey was needed to select a suitable drilling site. A reconnaissance was performed by three independent teams covering different parts of the area. It included in each case airborne and surface radio-echo 


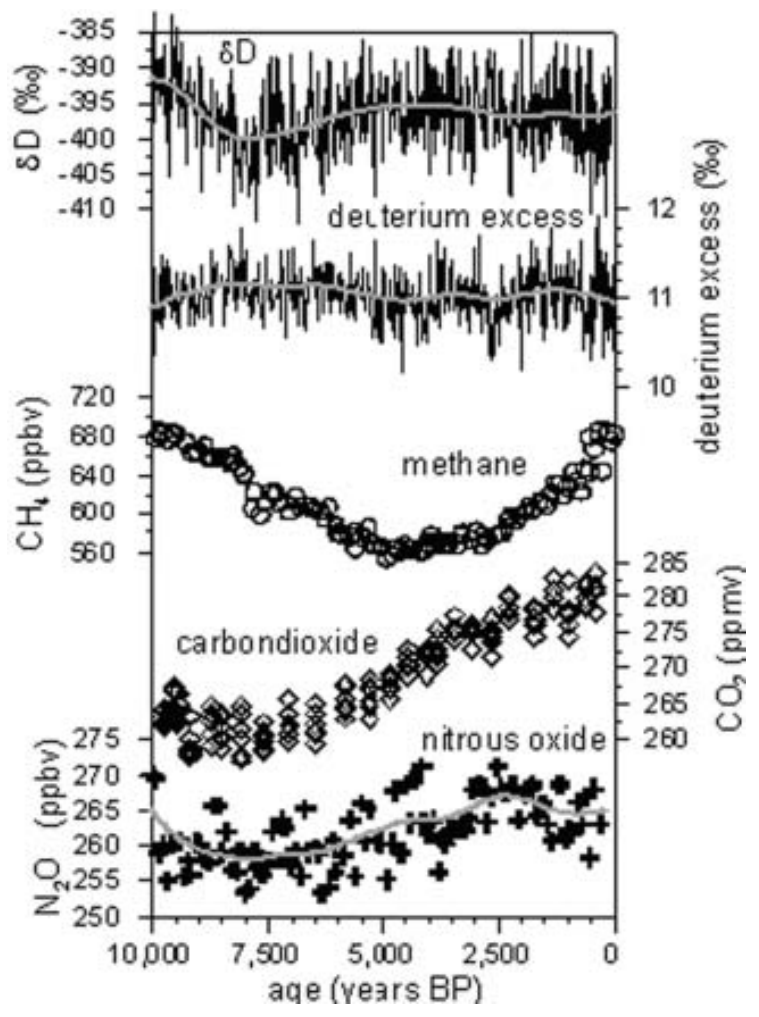

Fig. 1. Records of the deuterium $(\delta \mathrm{D})$ (Jouzel and others, 2001), the deuterium excess values (Stenni and others, 2001), the $\mathrm{CH}_{4}, \mathrm{CO}_{2}$ and $\mathrm{N}_{2} \mathrm{O}$ concentrations (Flückiger and others, 2002) along the depth interval of the Dome $\mathrm{C}$ ice core representing the Holocene. The grey lines are splines with a cut-off period of $3 \mathrm{kyr}$ (Enting, 1987).

sounding and the collection of snow samples from snow pits and by shallow core drillings, in a few cases down to $150 \mathrm{~m}$ depth. After 3 years of reconnaissance, a location east of Kottas camp at $75^{\circ} 00^{\prime} 06^{\prime \prime} \mathrm{S}, 00^{\circ} 04^{\prime} 04^{\prime \prime} \mathrm{E}$ was selected, based on a relatively flat bedrock and a reasonable accumulation rate, as the drilling site for the second EPICA deep ice coring. The location is at $2892 \mathrm{ma}$ a.s.l., and has a mean annual temperature of $-44.6{ }^{\circ} \mathrm{C}$ and a mean annual accumulation rate of about $64 \mathrm{~kg} \mathrm{~m}^{-2}$. During field season 2000/01, a camp was erected at the selected site, now called Kohnen station, and preparations for the deep drilling, including the excavation of the drill trench and the installation of the casing, were performed. Deep drilling started during field season 2001/02. The final depth achieved in the very short field season was $449 \mathrm{~m}$. Field season 2002/03 was much longer, as it was possible to transport people and equipment by air to Antarctica and Kohnen station. As a consequence, a depth of $1564.6 \mathrm{~m}$ was reached by the end of February 2003. The total ice thickness is about $2750 \mathrm{~m}$.

Results from DML are so far mainly available from the reconnaissance of the drill sites and from the analyses of the upper part of the Kohnen ice core. Many new results from the middle part of the Dome $\mathrm{C}$ and the top part of the Kohnen core are presented in this volume. In this paper, an interesting result from the analyses of shallow cores from DML and a few results from the top part of the Dome C core are summarized. In the following sections, first results measured in the field from the deepest part of the Dome C core are presented, and some perspectives for this exciting old ice are discussed.

\section{RECONNAISSANCE AND TOP PART OF THE TWO ICE CORES}

The reconnaissance in the DML area has resulted in a wealth of information on surface and bottom topography and on spatial and temporal variations of temperature and accumulation rates of this hitherto little-explored region of Antarctica. Chemical analyses on pit samples and shallow cores allowed identification of seasonal layers and provided new insight into an interesting climatic phenomenon.

The Antarctic Circumpolar Wave (ACW), characterized by periodic anomalies in sea-level pressure, sea-ice extent and sea-surface temperature, was recently observed with a periodicity of 4-5 years (Fischer and others, 2004). The short direct observation time does not allow assessment of the persistency of this phenomenon. It appears that the ACW influences the concentration of sea-salt aerosols of the snow in DML. About $60 \%$ of the snow deposited on the Antarctic plateau of DML originates from the Atlantic sector of the Southern Ocean. Trajectory investigations also show that transport velocities are highest during spring, when the sodium concentration has a seasonal maximum. The interannual variations of a stacked $\mathrm{Na}^{+}$record correlate with variations of the sea-level pressure in the source region between 1958 and 1984. Based on this correlation, it is concluded that interannual variations of the $\mathrm{Na}^{+}$concentration in ice cores from DML are proxies for the ACW. Spectral analyses of longer records show peak values of 4 and 5.5 years, but also a very clear maximum at 14 years. This is a strong indication that ACW has been a persistent phenomenon over the past two millennia, the time-span covered by the shallow ice cores used for the $\mathrm{Na}^{+}$ measurements.

The deep core from Kohnen station was processed in summer 2002 down to $449 \mathrm{~m}$ and in summer 2003 down to $1564 \mathrm{~m}$ at the Alfred Wegener Institute, Bremerhaven, Germany. First results are available, but it is too early for a general overview.

This is not, of course, the case with the Dome C core. Results from the upper $580 \mathrm{~m}$ of the Dome $\mathrm{C}$ core cover the Holocene, the transition from the last glacial epoch to the Holocene and the latest part of the last glacial epoch (Schwander and others, 2001).

In the record representing the Holocene (Fig. 1), the deuterium record $(\delta \mathrm{D})$ starts with a value of about $-390 \%$ at 10000 years BP, decreases thereafter to a value below $-400 \%$ at about 8000 years BP, at just about the time when a distinct cooling event is recorded in Greenland ice cores, and slightly increases afterwards to values around $-395 \%$ for the rest of the Holocene (Jouzel and others, 2001). The deuterium-excess record $d\left(d=\delta \mathrm{D}-8 \delta^{18} \mathrm{O}\right)$ shows a maximum at about 8000 years BP (Stenni and others, 2001). It then decreases and shows distinct minima at about 4500 and 2400 years BP. It is remarkable that the general trends of the $\delta \mathrm{D}$ and $d$ records are slightly anticorrelated, indicating that the temperature in the source region of the water vapour varied differently from the Dome $\mathrm{C}$ temperature. Gas analyses on ice representing the Holocene have allowed the reconstruction of a high-resolution record of the atmospheric $\mathrm{CO}_{2}, \mathrm{CH}_{4}$ and $\mathrm{N}_{2} \mathrm{O}$ concentrations (Flückiger and others, 2002). The $\mathrm{CO}_{2}$ record is generally in good agreement with the Taylor Dome record. Significant deviations are probably due to uncertainties of the age scale for the two cores. The $\mathrm{CH}_{4}$ record is in good agreement with 
other records from Antarctica and also from Greenland, taking into account the inter-polar concentration gradient. The distinct minimum of the $\mathrm{CH}_{4}$ concentration at 8200 years BP in Greenland ice cores is only faintly recognizable in the Dome $\mathrm{C}$ record. A model calculation taking into account the smoothing of the signal due to the much lower accumulation rate shows that a variation of the atmospheric $\mathrm{CH}_{4}$ concentration lasting only about 190 years is recorded in Greenland cores with an attenuation of $12 \%$, but in the Dome $\mathrm{C}$ core with one of $56 \%$ (Spahni and others, 2003). For $\mathrm{N}_{2} \mathrm{O}$ the Dome $\mathrm{C}$ record is the first to cover the entire Holocene with such a fine time resolution. The variations are small compared to variations parallel to Dansgaard/Oeschger events and to the glacial-Holocene transition. They are also relatively small compared to the analytical scatter of the results. However, the long-term trend (spline with a cut-off frequency of 3000 years) is likely to be significant. It is astonishing that the long-term trend is better correlated with the $\mathrm{CO}_{2}$ than with the $\mathrm{CH}_{4}$ record. This could be an indication that the ocean is responsible for the $\mathrm{N}_{2} \mathrm{O}$ variations. However, based on this similarity alone it is not possible to identify the mechanisms causing the $\mathrm{N}_{2} \mathrm{O}$ concentration changes. The measurement of the isotopic ratios $\delta^{15} \mathrm{~N}$ and $\delta^{18} \mathrm{O}$ could help to answer this question, but measurements would have to be performed with a high accuracy and it has to be kept in mind that the range of the isotopic signature of natural soil sources and of the ocean source is rather large.

Interesting new results have been obtained from the Dome $\mathrm{C}$ ice core covering the transition from the last glacial epoch to the Holocene. The $\delta \mathrm{D}$ record (Fig. 2) confirms the two-step warming starting at about $18 \mathrm{kyr} B \mathrm{P}$, and ending at about $14 \mathrm{kyr}$ BP, followed by a cooling trend, the Antarctic Cold Reversal (ACR), reaching the lowest temperatures between 13.5 and $12.5 \mathrm{kyr}$, and a second warming phase reaching the Holocene values at $11.5 \mathrm{kyr}$ BP (Jouzel and others, 2001). Based on model calculations, it is concluded that the relation between $\delta \mathrm{D}$ values and temperature is close to the present spatial ratio of about $7.6 \%{ }^{\circ} \mathrm{C}^{-1}$ (Stenni and others, 2001). This implies that the temperature change between the glacial maximum and the Holocene was about $9^{\circ} \mathrm{C}$. The deuterium-excess $d$ was used to estimate the change of the temperature at the source region: assumed to be mainly the Indian Ocean at about $40^{\circ} \mathrm{S}$. The estimated temperature change for the sea surface temperature is about $4.5^{\circ} \mathrm{C}$. The record of the deuterium-excess $d$ also shows a two-step shape, with a cold reversal beginning at about $13.2 \mathrm{kyr}$ BP. This implies a significant time lag between the ACR and the Ocean Cold Reversal (OCR) of 800 years (Stenni and others, 2001).

The dust record shows a very pronounced change between the glacial epoch and the Holocene (Delmonte and others, 2002a, b). The mean dust concentration during the glacial maximum was about 800 ppbw, and decreased during the transition to the mean Holocene value of about 15 ppbw. This is a change of more than a factor of 50 . For the dust fluxes, the accumulation rate, which changed almost a factor of two between the glacial epoch and the Holocene (Schwander and others, 2001), has to be taken into account. The decrease of the dust concentration started about 18 kyr BP and reached a value of about 30 ppbw during the ACR. After the ACR the concentration decreased sharply to its lowest value of about 6 ppbw and remained at this low concentration for about 200 years. The reason for this

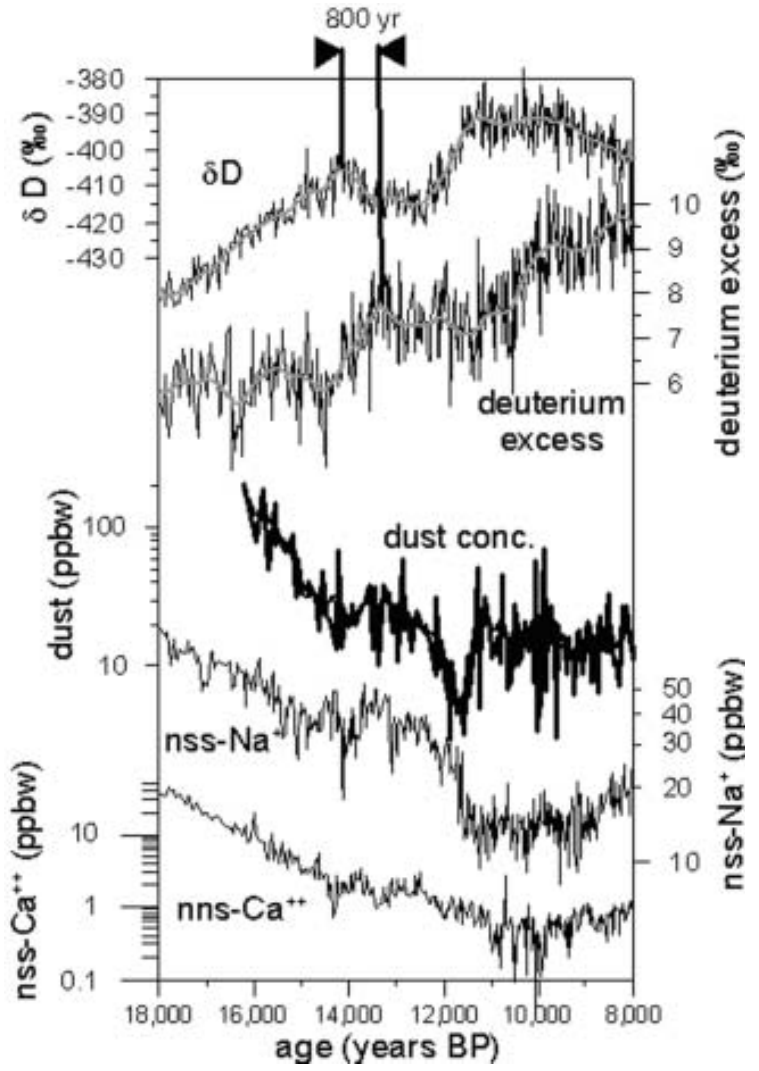

Fig. 2. Records of the deuterium $(\delta \mathrm{D})$ (Jouzel and others, 2001), the deuterium excess values (Stenni and others, 2001), the dust (Delmonte and others, 2002b), sodium and calcium (Röthlisberger and others, 2002) mass concentrations along a depth interval of the Dome $\mathrm{C}$ ice core covering the transition from the last glacial epoch to the Holocene. The grey lines and the thick black line for the dust are splines with a cut-off period of 500 years (Enting, 1987).

distinct and short minimum is assumed to be a wet climatic period in southern South America, supposed to be the main source for dust reaching East Antarctica. The period corresponds to the end of the Younger Dryas epoch in the Northern Hemisphere. About 99\% of the dust has a particle size of 0.7-5 $\mu \mathrm{m}$ (for the glacial epoch and the Holocene). Rather surprising is the finding that the mean particle size was larger during the Holocene than during the glacial epoch. This suggests a greater direct meridional transport of dust to the interior of Antarctica during the Holocene.

$\mathrm{Ca}^{2+}$ and $\mathrm{Na}^{+}$have been measured continuously with CFA already in the field (Röthlisberger and others, 2002). For the last glacial epoch, calcium is a typical terrestrial component, but during the Holocene about $50 \%$ is of marine origin. Sodium is a typical sea-salt component. From the measured concentrations, the non-sea-salt component of calcium $\left(\mathrm{nssCa}^{2+}\right)$ and the sea-salt component of sodium $\left(\mathrm{ssNa}^{+}\right)$have been calculated. The $\mathrm{nssCa}^{2+}$ concentration decreased by a factor of about 50 , and the $\mathrm{ssNa}^{+}$by about a factor of 5 from the glacial epoch to the Holocene. While both nssCa and ss Na concentrations started to decrease at about $18 \mathrm{kyr} B \mathrm{P}$, the decrease in nssCa was much more pronounced than in ss $\mathrm{Na}$, with nssCa changing by a factor of 23 and ssNa only by a factor of 2 from $18 \mathrm{kyr}$ to the ACR. During the ACR, nssCa and ssNa were rather stable, both at about twice the Holocene values. It is postulated that the large decrease in nssCa before the ACR is mainly due to 


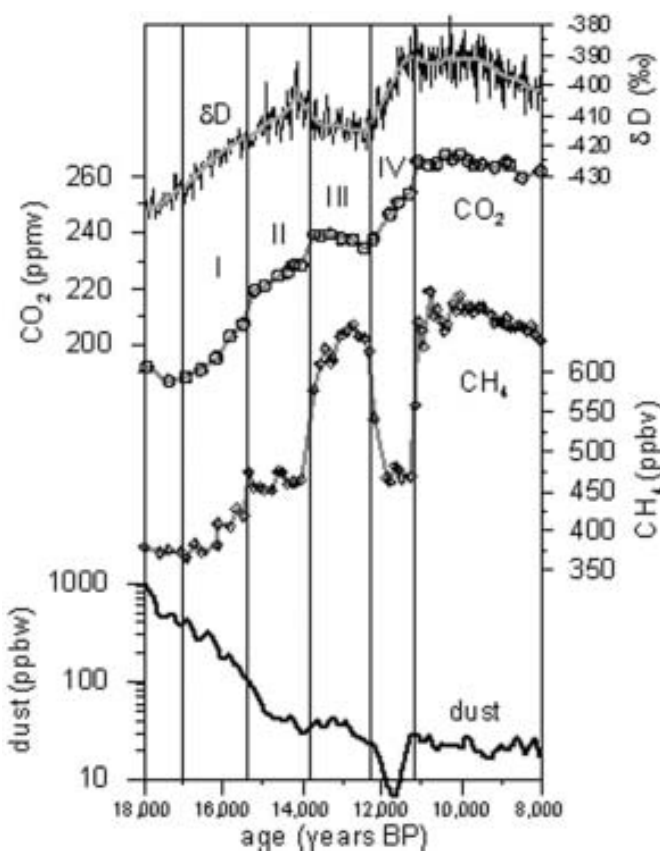

Fig. 3. Records of the deuterium (same record as in Fig. 2), the $\mathrm{CO}_{2}$, the $\mathrm{CH}_{4}$ and the dust (same record as in Figure 2, but only the spline) records. Dust is shown as surrogate for the iron concentration. The four intervals are selected based on the different rates of increase of the $\mathrm{CO}_{2}$ concentration.

changes in the dust source region, while the second, similar decrease of nssCa and ss Na from the ACR to the Holocene is mainly attributed to transport-related factors. The distinct dust minimum after the ACR is not seen in the nssCa record. However, this could be due to changes in dust composition, which could affect the dust/nssCa relationship (Ruth and others, 2002), and to some extent to the uncertainty in the measurements and in the calculation of nssCa.

The good core quality has also allowed the reconstruction of a very detailed $\mathrm{CO}_{2}$ record over the transition (Fig. 3) (Monnin and others, 2001). As is already known, the atmospheric $\mathrm{CO}_{2}$ concentration increased during about 6000 years by 76 ppmv. A new finding is that this increase occurred in four clearly distinguishable intervals. The increase started about $17 \mathrm{kyr} \mathrm{BP}$, and the additional interval limits are at 15.4, 13.8, 12.3 and $11.2 \mathrm{kyr}$. In the first and fourth intervals the rate of increase was about $20 \mathrm{ppmv} \mathrm{kyr}^{-1}$, in the second interval it was smaller and in the third interval even slightly negative. This third interval coincided with the ACR according to the official EPICA time-scale (Schwander and others, 2001) for the ice and the enclosed air. The increases in these four intervals are correlated quite well with the temperature increase according to the $\delta \mathrm{D}$ record and support the idea that the Southern Ocean played a key role in the atmospheric $\mathrm{CO}_{2}$ increase during the transition. However, there are interesting sharp increases at the end of intervals two and four. These sharp increases are, by comparison with the $\mathrm{CH}_{4}$ record, simultaneous with the fast warmings 14.5 and $11.7 \mathrm{kyr} \mathrm{BP}$ in the Northern Hemisphere (Dansgaard and others, 1993). These fast increases are, therefore, more likely caused by processes occurring in the Northern Hemisphere. Comparison of the $\mathrm{CO}_{2}$ and dust concentrations could answer the question whether a fertilization of the Southern Ocean played an important role in the $\mathrm{CO}_{2}$ increase. The dust concentration, shown again in Figure 3, starts to decrease before $\mathrm{CO}_{2}$ starts to increase. It decreases continuously until the end of interval two. It remains rather stable during interval three and shows, in interval four, the distinct minimum discussed already. More interesting would be the iron fluxes. Iron is an important fertilizer for the biological activity in the ocean and, therefore, the uptake of atmospheric $\mathrm{CO}_{2}$ by the ocean. With a decreasing Fe input, the Southern Ocean could take up less $\mathrm{CO}_{2}$ from the atmosphere (personal communication from C. Barbante, 2003.

The enclosed air is younger than the surrounding ice. The age difference is calculated to be about 2000 years during the Holocene and 5500 years during the glacial epoch (Schwander and others, 2001). The uncertainty of this age difference has to be taken into account when comparing gas with ice records. Comparing the $\delta \mathrm{D}$ record with the $\mathrm{CO}_{2}$ record, it was concluded that the beginning of the $\mathrm{CO}_{2}$ increase at the end of the last glacial epoch lagged the start of the temperature increase by $800 \pm 600$ years. This finding shows that atmospheric $\mathrm{CO}_{2}$ is unlikely to be the primary trigger signal for the end of the last glaciation, but this is not to question its role as probably the most important amplification factor for the temperature increase during the 6000 years of the transition.

\section{THE DOME C ICE CORE BELOW 788 M}

The need is most urgent for this part of the core to establish a reliable age scale down to the present depth of $3200.01 \mathrm{~m}$. For the top $788 \mathrm{~m}$ a tentative chronology was established by a group of EPICA scientists (Schwander and others, 2001) and adopted by the EPICA steering committee as the temporary official time-scale. It is based on an ice-flow model with a constant horizontal strain rate in the upper part of the ice sheet, a linearly decreasing strain rate below $1200 \mathrm{~m}$ and a certain sliding velocity at the bottom (Johnsen and Dansgaard, 1992). The different parameters in the model have been optimized to fit certain age control points. Down to 233 m depth (7100 years BP) various volcanoes have been used (Udisti and others, 2000), and for greater depth the end of the Younger Dryas cold period (11530 \pm 50 years) (Spurk and others, 1998) and the ${ }^{10} \mathrm{Be}$ maxima at $40 \mathrm{kyr} \mathrm{BP}$ (Yiou and others, 1997) which is found at about $742 \mathrm{~m}$ depth. The accuracy of the time-scale between 10 and $40 \mathrm{kyr}$ is estimated to be $2 \mathrm{kyr}$. The age scale can be extended with the same flow model if the accumulation rates in the past can be estimated, but there are only limited possibilities to adjust the flow parameters for the deeper part, because reliable age control points are missing. Down to an age of 420000 years the comparison of the ECM record with that from Vostok allows a certain control and shows that the extended age scale down to this depth is reasonable.

Parrenin (2002) has used a different glaciological flow model (Ritz, 1992) and used an inverse modelling method to optimize the parameters. He used chronological events similar to those used by Schwander and others for his inverse modelling. The results obtained suggest that the accumulation during glacial stages is underestimated if the usual relation between isotope ratio and accumulation is used (Parrenin, 2002). At the bottom of the ice sheet a small melting rate of $0-1 \mathrm{~mm} \mathrm{a}^{-1}$ is predicted, which is not unreasonable based on the measured temperature profile.

The two adjusted flow models give the same age for the top $788 \mathrm{~m}$ within the uncertainties. Extending the 


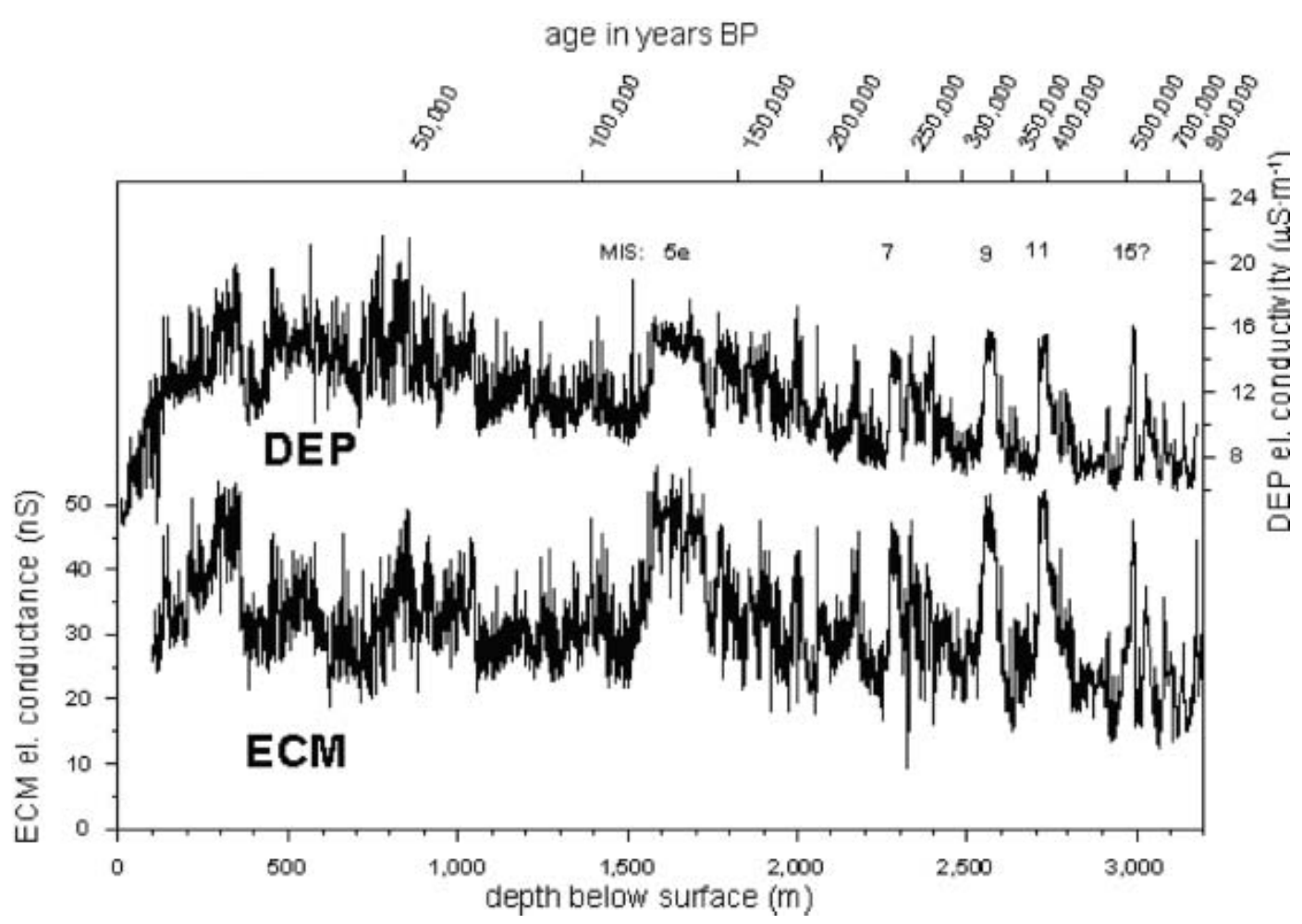

Fig. 4. DEP and ECM records along the entire length of the Dome $\mathrm{C}$ ice core. For DEP the conductivity measured at $100 \mathrm{kHz}$ is shown. DEP was measured with a resolution of $20 \mathrm{~mm}$, ECM with a resolution of $1 \mathrm{~mm}$. This figure shows $1 \mathrm{~m}$ averages. The measurements were performed on the EDC96 core down to $788 \mathrm{~m}$ and on the EDC99 core below.

calculation with unchanged flow parameters down to $3200 \mathrm{~m}$, both models give an age of about 900000 years for the ice at this depth. However, this age has an uncertainty of about 200000 years.

The calculated age scales have now to be compared with measurements along the ice core. As mentioned earlier, some measurements have been performed already in the field. The results of the dielectric profiling (DEP) and of the electrical conductivity measurements (ECM) are available, while the results from the chemical analyses by CFA and FIC have to be evaluated and partly calibrated. The DEP and ECM record are shown in Figure 4. DEP is performed along $2.2 \mathrm{~m}$ long sections of ice cores with the full cross-section. Conductance and capacitance are measured each $20 \mathrm{~mm}$ at different frequencies (Wolff and others, 1995). The record shown in Figure 4 gives the temperature-corrected conductivity at a frequency of $100 \mathrm{kHz}$. ECM needs a freshly cut surface. Seven electrodes are lowered to the surface each millimetre and the d.c. conductance is measured between each pair of electrodes. Present knowledge suggests that ECM measures the acidity in the ice while DEP also responds to other ions. The good correlation between the DEP and ECM record suggests that acidity generally dominates the DEP signal at Dome C. The increase of the DEP signal with increasing depth over the top $100 \mathrm{~m}$ is due to the increasing density. ECM has not been measured for the first $100 \mathrm{~m}$ of the firn core. Acidity in the ice at Dome $\mathrm{C}$ is high during interglacial epochs due to the higher accumulation rates which preserve $\mathrm{HCl}$ (Wolff, 1996), but it is also high during very cold periods with low accumulation rates, causing especially higher sulphate concentrations if it is assumed that the fluxes are constant. This can be seen by comparing the $\delta \mathrm{D}$ record, a proxy for the local temperature, and the DEP and ECM records over the past 40000 years shown in
Figure 5. This complicates the interpretation of the electrical records. However, a comparison of the ECM record from Dome $C$ with the ECM and $\delta \mathrm{D}$ record from Vostok (Petit and others, 1997) (Fig. 6) shows that the interglacials are characterized by the highest DEP and ECM signals during the past 420000 years. Marine isotope records suggest that interglacials before MIS11 (MIS: Marine Isotope Stage) have been rather weak. In this case, the accumulation rates may be smaller during previous interglacials so that $\mathrm{HCl}$ is less well preserved, and the ice with the highest impurity, especially sulphate concentrations, from the coldest epochs could show maxima of the DEP and ECM values (EPICA community members, 2004). However, we are still optimistic that the pronounced maxima represent whole glacial cycles and that the last maximum represents either stage MIS23 or, if it represents a cold period, the end of MIS24. It would be too optimistic to conclude that the electrical records confirm the age scales calculated based on ice-flow models, but at least they are rather a support than a contradiction.

The $\delta \mathrm{D}$ record along the ice core will certainly give more reliable information about the climatic cycles than the electrical records. However, it could be that the isotope record is not able to give a final answer either, because marine isotope records suggest that the climatic cycles before MIS stage 11 have been rather weak. In this case, $\delta^{18} \mathrm{O}$ measurements on $\mathrm{O}_{2}$ extracted from bubbles in the ice could allow a direct comparison with the isotope records of marine sediments (Bender and others, 1994), but a great number of these time-consuming measurements would be required.

If the age of the ice at $3200 \mathrm{~m}$ depth is 900000 years, it is also possible to estimate the mean annual layer thickness as a function of depth. A rough estimate shows that it is about 


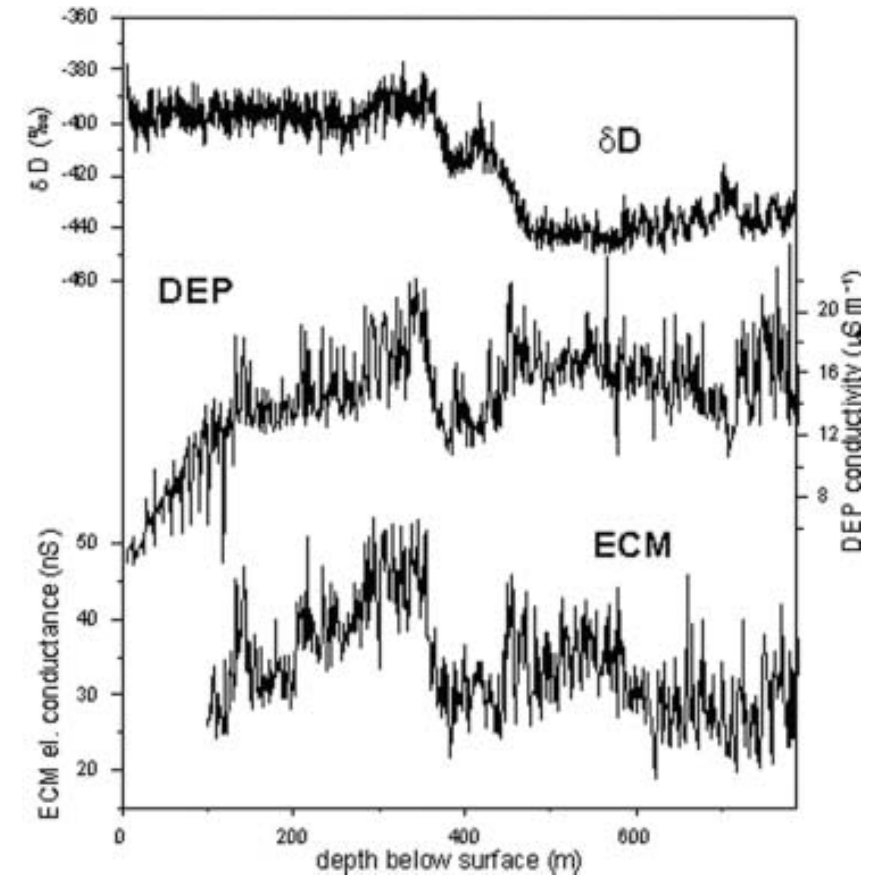

Fig. 5. Records of the deuterium $(\delta \mathrm{D})$, the DEP conductivity at $100 \mathrm{kHz}$ and the ECM conductance along the top $788 \mathrm{~m}$ of the Dome C core. The DEP and ECM records show high signals in the early Holocene as well as in the glacial maximum.

$1.2 \mathrm{~mm}$ at $2800 \mathrm{~m}$ depth where the ice has an age of about 450000 years, and $0.5 \mathrm{~mm}$ at $3200 \mathrm{~m}$ depth where the ice is estimated to be 900000 years old. The question arises to what detail climatic signals can be resolved in the deepest parts of the core. The ACR discussed above has a duration of about 1300 years, and the age difference between the beginning of the ACR and the OCR is about 800 years (Stenni and others, 2001). Such age differences correspond to depth intervals of 1.56 and $0.96 \mathrm{~m}$ at $2800 \mathrm{~m}$ depth and of 0.65 and $0.4 \mathrm{~m}$ at $3200 \mathrm{~m}$ depth. From an analytical point of view, the resolution of such an event is no problem, as long as the original characteristics of the climatic signals are not smoothed out by diffusion and as long as the stratigraphy is still preserved on the macro and on the micro scale.

Concerning the diffusion and redistribution of certain compounds, an interesting phenomenon has been observed in two dust layers of the ice core. The DEP and ECM signal over both dust layers at depths of 2788 and $2833 \mathrm{~m}$, respectively, are completely different as shown in Figure 7. The obviously alkaline dust layer causes an ECM minimum, but because DEP measures part of the other ions as well, this signal shows, at least in the lower dust band, a maximum. Preliminary results from FIC and CFA measurements showed that the peaks are mainly caused by high $\mathrm{Na}^{+}, \mathrm{Cl}^{2-}$ and $\mathrm{SO}_{4}{ }^{-}$concentrations (Barnes and others, 2003). The smaller broad minimum in the DEP and ECM records is due to the diffusion mainly of $\mathrm{H}^{+}$toward the dust layer to neutralize alkalinic compounds. Barnes and others (2003) have estimated effective diffusion constants based on the form of the different concentration peaks. The estimates are $8 \times 10^{-15} \mathrm{~m}^{2} \mathrm{~s}^{-1}$ for acidic species, $3 \times 10^{-16} \mathrm{~m}^{2} \mathrm{~s}^{-1}$ for nonacidic solubles and $3 \times 10^{-17} \mathrm{~m}^{2} \mathrm{~s}^{-1}$ for precipitates. This limits the temporal resolution of $\mathrm{H}^{+}$events to about 500 years (corresponding to about $0.6 \mathrm{~m}$ ) at about $2800 \mathrm{~m}$

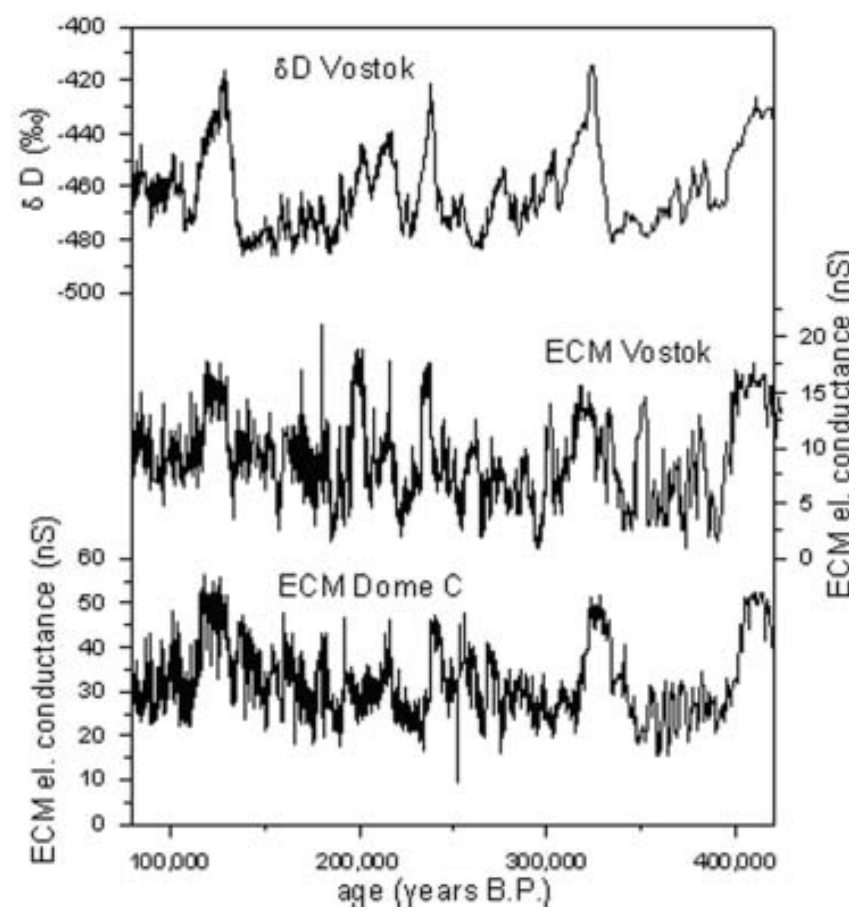

Fig. 6. Comparison of the deuterium record with the ECM record from the Vostok ice core (Petit and others, 1997) and with the ECM record of the Dome $C$ ice core for about the last 420,000 years. The absolute values of the ECM conductance depend on the arrangement and size of the electrodes. Since two different systems have been used at Vostok and at Dome $C$, the difference between the absolute values is not surprising.

depth, while immobile species still have a time resolution of better than 30 years ( $40 \mathrm{~mm}$ depth resolution).

The diffusion could also affect the isotope signals. Johnsen and others (2000) give an effective diffusion for $\delta^{18} \mathrm{O}$ which is an order of magnitude larger as measured on single crystals (about $3 \times 10^{-15} \mathrm{~m}^{2} \mathrm{~s}^{-1}$ for ice at $-32^{\circ} \mathrm{C}$ ). This would smooth sharp isotope signals by several hundreds of years in $500 \mathrm{kyr}$ old ice. It has also to be kept in mind that the diffusion of deuterium and ${ }^{18} \mathrm{O}$ is different, so that the interpretation of possible time lags between stable-isotope signals and the deuterium excess of less than a few hundred years will become difficult. These effects are larger close to bedrock where the temperature approaches the pressuremelting point.

The diffusion and permeation of gases, enclosed in clathrates at greater depth, is small (Ikeda and others, 1999). A substantial attenuation of gas signals in the ice (in the firn such an attenuation can be substantial!) or a fractionation of air components in a depth interval where gas concentrations vary within a few centuries is not expected.

Until now, we have assumed that variations of climatic proxies in the ice are only affected by diffusion. However, we know from the Greenland Icecore Project (GRIP) and Greenland Ice Sheet Project II (GISP-2) ice cores from central Greenland that the stratigraphy can be substantially disturbed several hundred metres above the bedrock. Microfolding was observed $500 \mathrm{~m}$ above bedrock in the GRIP ice core which was drilled on the present ice divide, and severe stratigraphic disturbances have started $200 \mathrm{~m}$ above bedrock (Alley and others, 1995). Some irregular features in the Dome $\mathrm{C}$ ice core have been observed at the depth of the two discussed dust layers. However, these features can be 


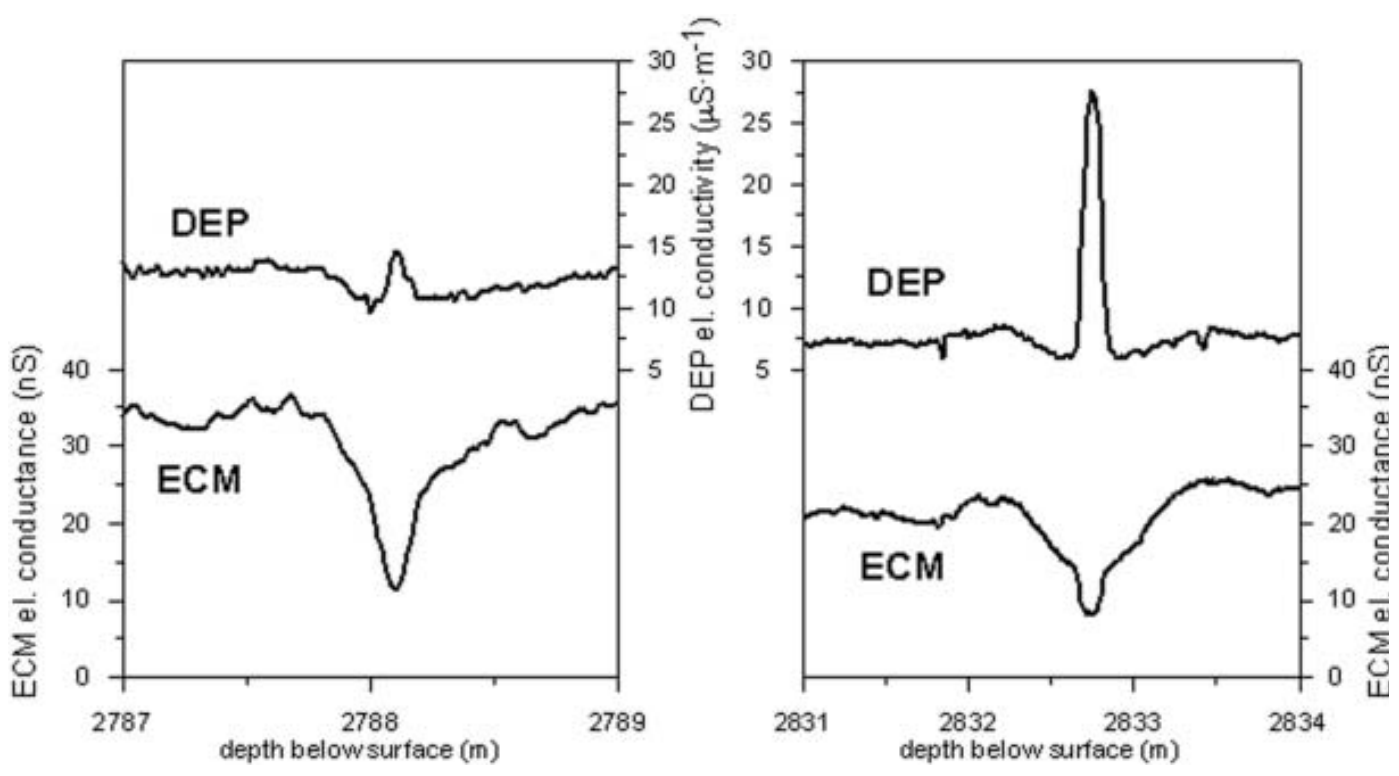

Fig. 7. Same records as in Figure 4 but of two small depth intervals over core sections containing visible dust layers. The depth resolutions are $20 \mathrm{~mm}$ for the DEP conductivity and $1 \mathrm{~mm}$ for the ECM conductance. Both records show broad minima, but superimposed in the DEP is a narrow maximum, in ECM a narrow minimum over each of the dust layers.

compared with the observation of the first micro-foldings at GRIP and do not indicate a severe stratigraphic disturbance. Dome C ice-core records below about $2800 \mathrm{~m}$ will remain questionable as long as the stratigraphy cannot be tested with reliable time markers below this depth. If the tentative extended time-scale is correct, we expect at a depth of about $3070 \mathrm{~m}$ ice from the time of the Matuyama-Brunhes magnetic reversal, which took place at $789 \pm 8 \mathrm{kyr}$ BP (Quidelleur and others, 2003). It is certainly the most important time marker in the lower part of the Dome C core, but the question arises as to how it can be identified in the ice.

There are small concentrations of dust in the ice core and there are also some ferromagnetic particles in the ice (Lanci and others, 2001). The question is only answerable from this dust if it is incorporated into the ice at the time of firn and ice formation, and aligned with the Earth's magnetic field, and further, if this is the case, only if the orientation remains unchanged over the long time in the ice sheet despite crystal growth and reorientation. This seems very unlikely but cannot be excluded and should be tested.

If a direct measurement of the remnant magnetization is not possible, there is still the possibility of identifying the reversal by radioisotopes produced in the atmosphere, such as ${ }^{10} \mathrm{Be}$ and ${ }^{36} \mathrm{Cl}$. The ${ }^{10} \mathrm{Be}$ found in Greenland and Antarctic ice cores is probably caused by the Laschamp event (Laj and others, 2000). The strength of the Earth magnetic dipole moment was only about $10 \%$ of its present value at this time. For a reversal, the dipole moment would pass through $0 \%$, so we can expect a slightly higher ${ }^{10}$ Be maximum.

Even if this important time marker can be found, there will remain some doubts about the interpretation of hopefully interesting and spectacular results. A confirmation will be urgent, but it will be a long time before a new core drilling at another site reaching $1 \mathrm{Myr}$ old ice can be realized. Therefore, it would be important to have a technique to drill replicate cores from a certain depth in the Dome $\mathrm{C}$ hole down to the bedrock. The availability of replicate cores would allow analytical results to be checked and additional high-resolution measurements to be performed. Measurements on a core just a few metres from the original one do not have the same value as a new core, but would still answer many critical questions.

\section{ACKNOWLEDGEMENTS}

This work is a contribution to the European Project for Ice Coring in Antarctica (EPICA), a joint European Science Foundation/European Commission scientific programme, funded by the European Commission and by national contributions from Belgium, Denmark, France, Germany, Italy, the Netherlands, Norway, Sweden, Switzerland and the United Kingdom. This is EPICA publication No. 80. We thank B. Stenni, B. Delmonte, C. Barbante, H. Fischer, F. Parrenin and J. Schwander for partly unpublished results and information, and the two reviewers D. Peel and W. Budd for their valuable suggestions and corrections which improved the original manuscript.

\section{REFERENCES}

Alley, R. B., A. J. Gow, S. J. Johnsen, J. Kipfstuhl, D. A. Meese and Th. Thorsteinsson. 1995. Comparison of deep ice cores. Nature, 373(6513), 393-394.

Barnes, P. R. F. and the EPICA Dome C 2002/03 science team. 2003. The electrical and chemical properties of visible dust layers in the deepest part of the Dome C ice core. Geophys. Res. Abstr., 5, EAE03-A-03676. (http://www.cosis.net/abstracts/EAE03/03676/ EAE03-J-03676.pdf)

Bender, M. and 6 others. 1994. Climate correlations between Greenland and Antarctica during the past 100,000 years. Nature, 372(6507), 663-666.

Dansgaard, W. and 10 others. 1993. Evidence for general instability of past climate from a 250-kyr ice-core record. Nature, 364(6434), 218-220.

Delmonte, B., J.-R. Petit and V. Maggi. 2002a. Glacial to Holocene implications of the new 27000-year dust record from the EPICA Dome C (East Antarctica) ice core. Climate Dyn., 18(8), 647-660. 
Delmonte, B., J.R. Petit and V. Maggi. 2002b. LGM-Holocene changes and Holocene millennial-scale oscillations of dust particles in the EPICA Dome C ice core, East Antarctica. Ann. Glaciol., 35, 306-312.

Enting, I. G. 1987. On the use of smoothing splines to filter $\mathrm{CO}_{2}$ data. J. Geophys. Res., 92(D9), 10,977-10,984.

EPICA community members. 2004. Eight glacial cycles from an Antarctic ice core. Nature, 429(692), 623-628.

Fischer, H., F. Traufetter, H. Oerter, R. Weller and H. Miller. 2004. Prevalence of the Antarctic Circumpolar Wave over the last two millennia recorded in Dronning Maud Land ice. Geophys. Res. Lett., 31(8). (10.1029/2003GL019186.)

Flückiger, J. and 7 others. 2002. High resolution Holocene $\mathrm{N}_{2} \mathrm{O}$ ice core record and its relationship with $\mathrm{CH}_{4}$ and $\mathrm{CO}_{2}$. Global Biogeochem. Cycles, 16(1), 1010. (10.1029/2001GB001417.)

Ikeda, T. and 7 others. 1999. Extreme fractionation of gases caused by formation of clathrate hydrates in Vostok Antarctic ice. Geophys. Res. Lett., 26(1), 91-94.

Johnsen, S. J. and W. Dansgaard. 1992. On flow model dating of stable isotope records from Greenland ice cores. In Bard, E. and W. S. Broecker, eds. The last deglaciation: absolute and radiocarbon chronologies. Berlin, etc., Springer-Verlag, 13-24. (NATO ASI Series I: Global Environmental Change 2.)

Johnsen, S. J., H. B. Clausen, K. M. Cuffey, G. Hoffmann, J. Schwander and T. Creyts. 2000. Diffusion of stable isotopes in polar firn and ice: the isotope effect in firn diffusion. In Hondoh, T., ed. Physics of ice core records. Sapporo, Hokkaido University Press, 121-140.

Jouzel, J. and 12 others. 2001. A new $27 \mathrm{kyr}$ high resolution East Antarctic climate record. Geophys. Res. Lett., 28(16), 3199-3202.

Laj, C., C. Kissel, A. Mazaud, J. E. Channel and J. Beer. 2000. North Atlantic palaeointensity stack since $75 \mathrm{ka}$ (NAPSIS-75) and the duration of Laschamp event. Philos. Trans. R. Soc. London, 358(1768), 1009-1025.

Lanci, L., D. V. Kent, P. E. Biscaye and A. Bory. 2001. Isothermal remanent magnetization of Greenland ice: preliminary results. Geophys. Res. Lett., 28(8), 1639-1642.

Monnin, E. and 7 others. 2001. Atmospheric $\mathrm{CO}_{2}$ concentrations over the last glacial termination. Science, 291(5501), 112-114.

Moore, J. C. 1993. High-resolution dielectric profiling of ice cores. J. Glaciol., 39(132), 245-248.

Parrenin, F. 2002. Datation glaciologique des forage profonds en Antarctique et modélisation concéptuelle des paléoclimats: implications pour la théorie astronomique des paléoclimats. (Ph.D. thesis, Université Joseph Fourier-Grenoble I.)

Petit, J.R. and 12 others. 1997. Four climate cycles in Vostok ice core. Nature, 387(6631), 359-360.

Quidelleur, X., J. Carlut, V. Soler, P. Valet and Y. Gillot. 2003. The age and duration of the Matuyama-Brunhes transition from new
$\mathrm{K}-\mathrm{Ar}$ data from La Palma (Canary Islands) and revisited ${ }^{40} \mathrm{Ar} /{ }^{39} \mathrm{Ar}$ ages. Earth Planet. Sci. Lett., 208(3-4), 149-163.

Ritz, C. 1992. Un modèle thermo-mécanique d'évolution pour le bassin glaciaire Antarctique Vostok-glacier Byrd: sensibilité aux valeurs des paramètres mal connus. (Thèse de doctorat d'état, Université Joseph Fourier - Grenoble I.)

Röthlisberger, R. and 6 others. 2000. Technique for continuous high-resolution analysis of trace substances in firn and ice cores. Environ. Sci. Technol., 34(2), 338-342.

Röthlisberger, R. and 6 others. 2002. Dust and sea salt variability in central East Antarctica (Dome C) over the last 45 kyrs and its implications for southern high-latitude climate. Geophys. Res. Lett., 29(20), 1963. (10.1029/2002GL015186.)

Ruth, U., D. Wagenbach, M. Bigler, J. P. Steffensen, R. Röthlisberger and $\mathrm{H}$. Miller. 2002. High-resolution microparticle profiles at NorthGRIP, Greenland: case studies of the calcium-dust relationship. Ann. Glaciol., 35, 237-242.

Schwander, J., J. Jouzel, C. U. Hammer, J. R. Petit, R. Udisti and E. Wolff. 2001. A tentative chronology for the EPICA Dome Concordia ice core. Geophys. Res. Lett., 28(22), 4243-4246.

Spahni, R., J. Schwander, J. Flückiger, B. Stauffer, J. Chappellaz and D. Raynaud. 2003. The attenuation of fast atmospheric $\mathrm{CH}_{4}$ variations recorded in polar ice cores. J. Geophys. Res., 30(11). 1571. (10.1029/2003GL017093.)

Spurk, M. and 6 others. 1998. Revisions and extensions of the Hohenheim oak and pine chronologies: new evidence about the timing of the Younger Dryas/Preboreal transition. Radiocarbon, 40(3), 1107-1116.

Stenni, B. and 7 others. 2001. An oceanic cold reversal during the last deglaciation. Science, 293(5537), 2074-2077.

Tabacco, I. E., A. Passerini, F. Corbelli and M. Gorman. 1998. Correspondence. Determination of the surface and bed topography at Dome C, East Antarctica. J. Glaciol., 44(146), 185-191.

Udisti, R. and 6 others. 2000. Holocene electrical and chemical measurements from the EPICA-Dome C ice core. Ann. Glaciol., 30, 20-26.

Wolff, E. W. 1996. Location, movement and reactions of impurities in solid ice. In Wolff, E.W. and R.C. Bales, eds. Chemical exchange between the atmosphere and polar snow. Berlin, etc., Springer-Verlag, 541-560. (NATO ASI Series I: Global Environmental Change 43.)

Wolff, E. W., J. C. Moore, H. B. Clausen, C. U. Hammer, J. Kipfstuhl and K. Fuhrer. 1995. Long-term changes in the acid and salt concentrations of the Greenland Ice Core Project ice core from electrical stratigraphy. J. Geophys. Res., 100(D8), 16,249$16,263$.

Yiou, F. and 11 others. 1997. Beryllium 10 in the Greenland Ice Core Project ice core at Summit, Greenland. J. Geophys. Res., 102(C12), 26,783-26,794. 